\title{
Growth and nutrient contents in lowland rice due to phosphorus and potassium fertilization ${ }^{1}$
}

\author{
André Fróes de Borja Reis ${ }^{2}$, Adriano Stephan Nascente ${ }^{3}$, \\ Rodrigo Estevam Munhoz de Almeida ${ }^{4}$, Aloísio Freitas Chagas Júnior ${ }^{5}$
}

\section{ABSTRACT}

In order to reach an optimum and sustainable production, growers must know the fertilizing potassium $(\mathrm{K})$ and phosphorous $(\mathrm{P})$ application rates. The present study aimed to determine the rice development in response to combined rates of $\mathrm{P}$ and $\mathrm{K}$, on Plinthaquults (380-400 $\mathrm{g} \mathrm{kg}^{-1}$ of clay), under high and low fertility conditions, in the tropical lowland plain of the Araguaia river, Brazil. Three field experiments were performed, each one consisting of a completely randomized factorial block design, with three replications. Treatments included a combination of six $\mathrm{K}_{2} \mathrm{O}$ rates $\left(0 \mathrm{~kg} \mathrm{ha}^{-1}\right.$, $30 \mathrm{~kg} \mathrm{ha}^{-1}, 60 \mathrm{~kg} \mathrm{ha}^{-1}, 90 \mathrm{~kg} \mathrm{ha}^{-1}, 120 \mathrm{~kg} \mathrm{ha}^{-1}$ and $\left.150 \mathrm{~kg} \mathrm{ha}^{-1}\right)$ with six $\mathrm{P}_{2} \mathrm{O}_{5}$ rates $\left(0 \mathrm{~kg} \mathrm{ha}^{-1}, 30 \mathrm{~kg} \mathrm{ha}^{-1}, 60 \mathrm{~kg} \mathrm{ha}^{-1}, 90 \mathrm{~kg} \mathrm{ha}^{-1}\right.$, $120 \mathrm{~kg} \mathrm{ha}^{-1}$ and $\left.150 \mathrm{~kg} \mathrm{ha}^{-1}\right)$. No interaction effect between $\mathrm{P}$ and $\mathrm{K}$ rates was observed for the evaluated variables in any fertility level/year. Phosphorous application under low fertility conditions, as well as $\mathrm{K}$ under high fertility conditions, affect overall crop nutrition, tillering capacity, yield components and grain yield of lowland rice, though no effects were observed due to the $\mathrm{P}$ application in high fertility soils and $\mathrm{K}$ in low fertility soils. Under high fertility conditions, the grain yield increment rate due to the $\mathrm{K}$ application was $4.04 \mathrm{~kg} \mathrm{ha}^{-1}$, whereas in the low fertility areas, such as recently cleared fields, a maximum yield of 7,161 $\mathrm{kg} \mathrm{ha}^{-1}$ was achieved by applying $140 \mathrm{~kg} \mathrm{ha}^{-1}$ of $\mathrm{P}$.

KEYWORDS: Oryza sativa; irrigated rice; tropical soil.

\section{INTRODUCTION}

Rice (Oryza sativa) is one of the most important grains for human consumption throughout the world (Nascente et al. 2013, Heinemann et al. 2017). In Brazil, as in other world regions, this crop can be grown in two ecosystems: lowland and upland (Fageria et al. 2003). In lowland ecosystems, rice can

\section{RESUMO}

Crescimento e teores de nutrientes em arroz de terras baixas em razão de adubação com fósforo e potássio

A fim de obter uma produção ótima e sustentável, os produtores precisam conhecer a taxa de aplicação de potássio (K) e fósforo (P) fertilizante. Objetivou-se determinar o desenvolvimento de arroz, em resposta a taxas combinadas de $\mathrm{P}$ e K, em Plintosolos (380-400 $\mathrm{g} \mathrm{kg}^{-1}$ de argila), em condições de fertilidade alta e baixa, na planície irrigável tropical do rio Araguaia. Foram instalados três experimentos, sendo que cada um deles consistiu em delineamento fatorial em blocos casualizados, com três repetições. Os tratamentos incluíram a combinação de seis doses de $\mathrm{K}_{2} \mathrm{O}\left(0 \mathrm{~kg} \mathrm{ha}^{-1}, 30 \mathrm{~kg} \mathrm{ha}^{-1}, 60 \mathrm{~kg} \mathrm{ha}^{-1}, 90 \mathrm{~kg} \mathrm{ha}^{-1}, 120 \mathrm{~kg} \mathrm{ha}^{-1}\right.$ e $\left.150 \mathrm{~kg} \mathrm{ha}^{-1}\right)$ com seis doses de $\mathrm{P}_{2} \mathrm{O}_{5}\left(0 \mathrm{~kg} \mathrm{ha}^{-1}, 30 \mathrm{~kg} \mathrm{ha}^{-1}\right.$, $60 \mathrm{~kg} \mathrm{ha}^{-1}, 90 \mathrm{~kg} \mathrm{ha}^{-1}, 120 \mathrm{~kg} \mathrm{ha}^{-1}$ e $150 \mathrm{~kg} \mathrm{ha}^{-1}$ ). Não foi observado efeito da interação entre doses de $\mathrm{P}$ e K nas variáveis analisadas em nenhum nível de fertilidade/ano. A aplicação de P sob condição de baixa fertilidade, bem como de $\mathrm{K}$ sob alta fertilidade, afetam a nutrição da cultura de forma geral, capacidade de perfilhamento, componentes da produtividade e rendimento de grãos de arroz de terras baixas, embora não tenha sido observado efeito da aplicação de $\mathrm{P}$ em área de alta fertilidade e $\mathrm{K}$ na área de baixa fertilidade. $\mathrm{Na}$ condição de alta fertilidade, a taxa de incremento de rendimento de grãos devida à aplicação de $\mathrm{K}$ foi de $4,04 \mathrm{~kg} \mathrm{ha}^{-1}$, e na condição de baixa fertilidade, como áreas recém-abertas, a produtividade máxima foi de $7.161 \mathrm{~kg} \mathrm{ha}^{-1}$, quando aplicados $140 \mathrm{~kg} \mathrm{ha}^{-1} \mathrm{de} \mathrm{P}$.

PALAVRAS-CHAVE: Oryza sativa; arroz irrigado; solo tropical.

be cultivated in floodplains with water control and in not systematized soils irrigated by rainwater or by raising the water table.

As the human population continues to grow and competition for natural resources increases, there is a consequent need to produce more food in a sustainable way. The available area for sustainable irrigation in Brazil is about 30 million ha, $50.6 \%$ of which could

1. Manuscript received in Dec./2017 and accepted for publication in Apr./2018 (http://dx.doi.org/10.1590/1983-40632018v4850666).

2. Universidade de São Paulo, Escola Superior de Agricultura “Luiz de Queiroz”, Piracicaba, SP, Brasil.E-mail: andrefbr@usp.br.

3. Empresa Brasileira de Pesquisa Agropecuária (Embrapa Arroz e Feijão), Santo Antônio de Goiás, GO, Brasil.

E-mail: adriano.nascente@embrapa.br.

4. Empresa Brasileira de Pesquisa Agropecuária (Embrapa Pesca e Aquicultura), Palmas, TO, Brasil.

E-mail: rodrigo.almeida@embrapa.br.

5. Universidade Federal do Tocantins, Gurupi, TO, Brasil.E-mail: chagasjraf@mail.uft.edu.br. 
be made up by irrigable floodplains (Coelho et al. 2006). However, currently, less than 3 million ha of these areas are under cultivation (Fageria et al. 2015). Hence, this is one of the largest land areas available in the world to produce food and fiber.

Lowland tropical soils, such as Plintossolo (Santos et al. 2006), or Ultisols, according to the Soil Taxonomy Classification (USDA 2014), which are naturally acidic due to the leaching of basic ions from high rainfall, result in a reduced soil fertility (Fageria \& Nascente 2014). Thus, this tropical soil has a low natural availability of phosphorus (P) because of the low nutrient content in available form to plants or by high nutrient complexion rates due to the fixing element reactions with soil particles (Fageria \& Nascente 2014). Cultivation systems require a constant $\mathrm{P}$ application, in relatively large quantities, to ensure the productivity of crops, which translates in an increase in production costs. Several studies have shown the positive effect of $\mathrm{P}$ fertilization in rice growth, yield components and grain yield (George et al. 2001, Crusciol et al. 2005, Fageria et al. 2013, Nascente et al. 2014).

The consumption of $\mathrm{K}$ in crop systems has increased year by year (Dobermann \& White 1999, Nelson et al. 2010, Fageria 2015). Potassium deficiency in annual crops is widely reported in many countries (Dobermann \& White 1999, Nelson et al. 2010, Fageria 2015). It is extracted in large amounts from soils by rice plants (Farinelli et al. 2004, Slaton et al. 2009, Fageria et al. 2013, Crusciol et al. 2016) and plays a significant role in many physiological and biochemical processes in plants. It can also control many plant diseases and provide tolerance to drought, heat and cold (Qian et al. 1997, Fageria 2009, Rowland et al. 2010).

In lowland tropical soils, satisfactory cash crop grain yields are dependent on proper performing of liming and soil fertilization (Caires et al. 2001, Alleoni et al. 2010, Souza et al. 2011, Nascente \& Cobucci 2015). Therefore, soil fertilization (including $\mathrm{P}$ and $\mathrm{K}$ ) is one of the most important factors that improve crop yield on lowland Ultisols in the tropical region (Fageria et al. 2010 and 2011c). An adequate and balanced supply of nutrients provides a suitable crop development with a positive effect on grain yield (Fageria et al. 2011a, Pagani \& Mallarino 2012, Crusciol et al. 2013).

Phosphorus and potassium requirements from rice plants vary greatly depending on the cultivar, nutrient supply, crop management and climatic conditions (Cassman et al. 1996, Dobermann \& White 1999, Fageria 2015). According to Barberena et al. (2011), who studied $\mathrm{P}$ and $\mathrm{K}$ responses in a silty clay Aqueptsoil with $2.5 \mathrm{ppm}$ of $\mathrm{P}$ (Mehlich) and $0.17 \mathrm{cmol} \mathrm{dm}^{-3}$ of $\mathrm{K}$ (Mehlich), in Brazil, the highest yield found $\left(8,154 \mathrm{~kg} \mathrm{ha}^{-1}\right.$ of grains) occurred with the use of $304 \mathrm{~kg} \mathrm{ha}^{-1}$ of $\mathrm{P}_{2} \mathrm{O}_{5}$ and $228 \mathrm{~kg} \mathrm{ha}^{-1}$ of $\mathrm{K}_{2} \mathrm{O}$. It is estimated that, for each ton of rice grain, the total removal ranged from $2 \mathrm{~kg}$ to $11 \mathrm{~kg}$ for $\mathrm{P}$ and from $16 \mathrm{~kg}$ to $50 \mathrm{~kg}$ for K (Cassman et al. 1996, Dobermann \& White 1999, Fageria 2015).

There are few studies on lowland tropical soils, regarding the $\mathrm{P}$ and $\mathrm{K}$ influence on rice crops. Therefore, this study aimed to determine the rice development in response to combined rates of $\mathrm{P}$ and $\mathrm{K}$ on Ultisols, under high and low fertility conditions, in the tropical lowland of the Tocantins state.

\section{MATERIAL AND METHODS}

The experiments were conducted in a farm field at Lagoa da Confusão (1049'34.78" S, 4954'0.33"W and $180 \mathrm{~m}$ of altitude), Tocantins state, Brazil, from September 2010 to March 2012. The climate is humid tropical savannah Awi, according to the Köppen classification (Alvares et al. 2014), and there are two well-defined seasons: a normally dry season from May to September (autumn/winter) and a rainy season from October to April (spring/summer). During the period of this study, the temperature and the rainfall precipitation data were recorded (Figure 1).

The soil is classified as Plinthaquults (USDA 2014) or Plintossolo Háplico (Santos et al. 2006). Prior to the study, in November 2010 and 2011, chemical analyses (Silva 1999) were performed for the initial characterization of the area (Table 1).

There were two distinct soil chemical fertility levels: high and low. The first area was cultivated for four consecutive years, with two annual crops, rice (summer) and soybean (winter), and soil fertility was considered adequate for rice crop development (Table 1; Sousa \& Lobato 2004). The second area was a new cropland converted from pasture to agriculture, where $4 \mathrm{Mg} \mathrm{ha}^{-1}$ of lime $(30 \%$ of $\mathrm{CaO}$ and $19.2 \%$ of $\mathrm{MgO})$ were applied three months before rice sowing, based on a previous report by Fageria (2011b). In the second area, the trial was performed for two consecutive years, but not in the same plots, in order to have both years with low fertility levels. 


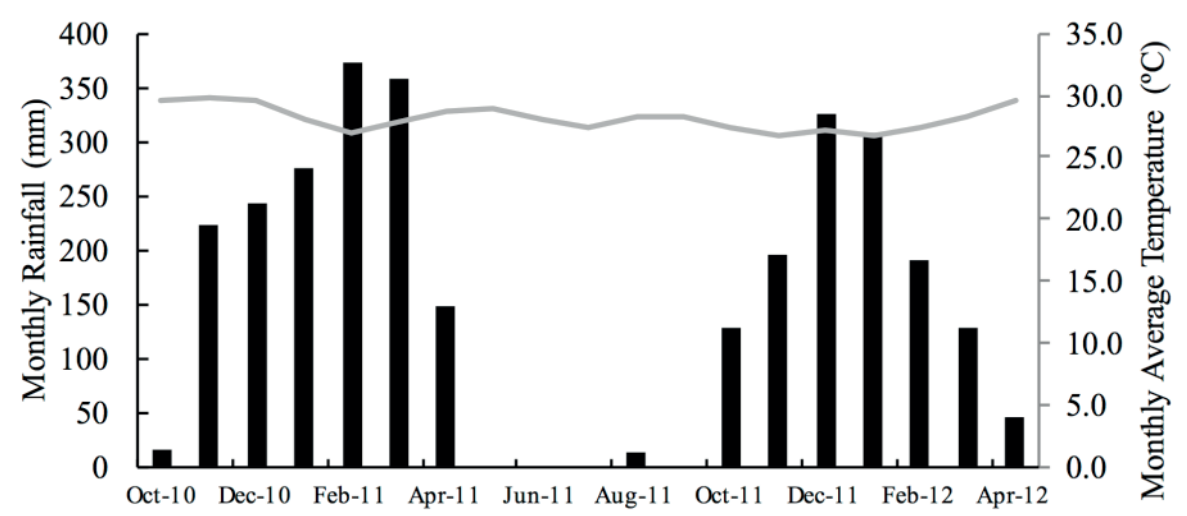

Figure 1. Temperature and rainfall during the trials, in Lagoa da Confusão, Tocantins state, Brazil, in the 2010/2011 and 2011/2012 growing seasons.

Table 1. Soil chemical attributes of a Plinthaquults, in the experimental area.

\begin{tabular}{|c|c|c|c|c|c|c|c|c|c|c|c|c|c|}
\hline \multirow{2}{*}{ Soil characteristic } & $\mathrm{Ca}$ & $\mathrm{Mg}$ & $\mathrm{H}+\mathrm{Al}$ & $\mathrm{K}$ & CEC & $\mathrm{P}$ & SOM & $\mathrm{BS}$ & \multirow{2}{*}{$\underset{\mathrm{cH}}{\mathrm{pHCl}{ }_{2}}$} & \multirow{2}{*}{$\begin{array}{c}\mathrm{pH} \\
\text { water }\end{array}$} & Clay & \multirow{2}{*}{$\frac{\text { Silt }}{\mathrm{g} \mathrm{kg}^{-1}}$} & \multirow{2}{*}{ Sand } \\
\hline & \multicolumn{5}{|c|}{$\mathrm{cmol}_{\mathrm{c}} \mathrm{kg}^{-1}$} & $\mathrm{mg} \mathrm{kg}^{-}$ & $\mathrm{g} \mathrm{kg}^{-1}$ & $\%$ & & & $\mathrm{~g} \mathrm{~kg}^{-1}$ & & \\
\hline \multicolumn{14}{|c|}{ 2010/2011 growing season } \\
\hline Low fertility & 0.5 & 0.3 & 4.1 & 0.01 & 4.9 & 3.0 & 5.8 & 17 & 4.5 & 4.4 & 390 & 250 & 360 \\
\hline \multicolumn{14}{|c|}{$2011 / 2012$ growing season } \\
\hline High fertility & 4.5 & 3.4 & 3.7 & 0.20 & 11.8 & 13.0 & 6.2 & 68 & 6.1 & 5.5 & 380 & 280 & 340 \\
\hline Low fertility & 0.9 & 0.4 & 3.8 & 0.01 & 5.1 & 3.1 & 6.1 & 26 & 5.0 & 4.8 & 400 & 250 & 350 \\
\hline
\end{tabular}

SOM: soil organic matter; BS: base saturation; CEC: cation exchange capacity.

Trials were arranged in a complete randomized block design, in a $6 \times 6$ factorial scheme, with three replications. The treatments consisted of combining six $\mathrm{P}_{2} \mathrm{O}_{5}$ rates $\left(0 \mathrm{~kg} \mathrm{ha}^{-1}, 30 \mathrm{~kg} \mathrm{ha}^{-1}, 60 \mathrm{~kg} \mathrm{ha}^{-1}\right.$, $90 \mathrm{~kg} \mathrm{ha}^{-1}, 120 \mathrm{~kg} \mathrm{ha}^{-1}$ and $150 \mathrm{~kg} \mathrm{ha}^{-1}$, as triple superphosphate) with six $\mathrm{K}_{2} \mathrm{O}$ rates $\left(0 \mathrm{~kg} \mathrm{ha}^{-1}\right.$, $30 \mathrm{~kg} \mathrm{ha}^{-1}, 60 \mathrm{~kg} \mathrm{ha}^{-1}, 90 \mathrm{~kg} \mathrm{ha}^{-1}, 120 \mathrm{~kg} \mathrm{ha}^{-1}$ and $150 \mathrm{~kg} \mathrm{ha}^{-1}$, as potassium chloride), during two growing seasons (2010/2011 and 2011/2012) for low soil fertility and in one growing season (2011/2012) for high soil fertility. Potassium was applied on the soil surface one day before sowing and phosphorus was applied in the sowing furrow together with rice seeds. Plots dimensions were $1.7 \mathrm{~m}(10$ rice rows $) \times$ $6 \mathrm{~m}$.

Cover crops were desiccated with one glyphosate application (1.8 $\mathrm{kg} \mathrm{ha}^{-1}$ of acid equivalent) at 30 days before sowing the lowland rice cultivar 'IRGA 424'. Sowing was performed mechanically, using $80 \mathrm{~kg} \mathrm{ha}^{-1}$ of dry rice seeds, in a row spacing of $0.17 \mathrm{~m}$. Rice seeds were sown on 4 December 2010 and 12 December 2011 (low soil fertility) and on 6 December 2011 (high soil fertility). On average, rice plants emergence occurred at five days after sowing for both growing seasons. Phosphorus and $\mathrm{K}$ fertilization was done according to each treatment and $\mathrm{N}$ fertilization only as topdressing at 20 and 35 days after rice emergence for all treatments. For this, $45 \mathrm{~kg} \mathrm{ha}^{-1}$ of $\mathrm{N}$ (as urea) were applied on the soil surface in each application. Rice was flooded at 45 days after germination and drained 13 days before harvesting. Cultural practices were performed according to standard recommendations for a rice crop to keep the area free from weeds, diseases and insects.

Rice leaf samples were collected from the flag leaf at the full blooming stage. Leaves from 50 plants per plot were collected, washed and dried under forced-air circulation at $65^{\circ} \mathrm{C}$, for $72 \mathrm{~h}$, before grinding and analyzing the samples for chemical composition. The concentrations of $\mathrm{N}, \mathrm{P}, \mathrm{K}, \mathrm{Ca}, \mathrm{Mg}$, $\mathrm{Cu}, \mathrm{Zn}, \mathrm{Fe}$ and $\mathrm{Mn}$ were determined using methods described by Silva (1999).

Rice harvest was carried out by hand at physiological maturity. Plots were evaluated for the number of tillers per hill, determined by counting 10 plants per plot. Panicle density (panicle $\mathrm{m}^{-2}$ ) was determined by counting the number of panicles within $1.0 \mathrm{~m}$ length and dividing by the row spacing. Panicle 
biomass was evaluated as the average weight of the collected panicles in $1.0 \mathrm{~m}$ length. Grain yield was determined by harvesting $3.0 \mathrm{~m}^{2}$ and converting it to $\mathrm{kg} \mathrm{ha}^{-1}$. Panicle biomass and yield were corrected to a $13 \%$ moisture basis.

The R software, version 3.1.2 (R Studio Team, Boston, MA) was used for statistical analysis. For qualitative factors (growing seasons for the areas with low soil fertility), data were subjected to variance analysis, and when the $\mathrm{F}$ test proved significant, the data were compared by the Tukey test at $\mathrm{p}<0.05$. For quantitative factors ( $\mathrm{P}$ and $\mathrm{K}$ rates), data were subjected to variance analysis, and when the $\mathrm{F}$ test proved significant, results were submitted to regression analyses.

\section{RESULTS AND DISCUSSION}

Interaction effects of $\mathrm{P}$ and $\mathrm{K}$ rates on the evaluated variables were not significant(Tables 2 and 3 ).

Table 2. Variance analyses of nutrient content in lowland rice flag leaf, as affected by $\mathrm{P}_{2} \mathrm{O}_{5}$ and $\mathrm{K}_{2} \mathrm{O}$ rates and growing season, in areas with low and high soil fertility.

\begin{tabular}{|c|c|c|c|c|c|c|c|c|c|}
\hline \multicolumn{10}{|c|}{ Low soil fertility } \\
\hline \multirow{2}{*}{ Growing season } & $\mathrm{N}$ & $\mathrm{P}$ & $\mathrm{K}$ & $\mathrm{Ca}$ & $\mathrm{Mg}$ & $\mathrm{Cu}$ & $\mathrm{Fe}$ & $\mathrm{Mn}$ & $\mathrm{Zn}$ \\
\hline & \multicolumn{5}{|c|}{$\mathrm{g} \mathrm{kg}^{-1}$} & \multicolumn{4}{|c|}{$\mathrm{mg} \mathrm{kg}^{-1}$} \\
\hline $2010 / 2011$ & $23.44 \mathrm{a}$ & 1.36 & $8.60 \mathrm{a}$ & 4.42 & 1.24 & 7.37 & 53.53 & 362 & $20.07 \mathrm{~b}$ \\
\hline $2011 / 2012$ & $19.29 \mathrm{~b}$ & 1.08 & $7.28 \mathrm{~b}$ & 5.86 & 0.97 & 4.78 & 45.76 & 445 & $25.44 \mathrm{a}$ \\
\hline Factors & \multicolumn{9}{|c|}{ Anova (F probability) } \\
\hline Growing season (GS) & $<0.01$ & $<0.01$ & $<0.01$ & $<0.01$ & $<0.01$ & $<0.01$ & $<0.01$ & $<0.01$ & $<0.01$ \\
\hline Phosphorus rates $(\mathrm{P})$ & $<0.001$ & $<0.01$ & $<0.01$ & $<0.01$ & $<0.01$ & $<0.01$ & 0.09 & $<0.01$ & 0.02 \\
\hline Potassium rates $(\mathrm{K})$ & 0.3307 & 0.13 & 0.1195 & 0.825 & 0.439 & 0.149 & 0.331 & 0.110 & 0.301 \\
\hline GS $\times$ P & 0.8593 & $<0.01$ & 0.0965 & $<0.01$ & $<0.01$ & $<0.01$ & $<0.01$ & $<0.01$ & 0.225 \\
\hline GS $x \mathrm{~K}$ & 0.153 & 0.805 & 0.942 & 0.270 & 0.451 & 0.168 & 0.294 & 0.847 & 0.067 \\
\hline $\mathrm{P} \times \mathrm{K}$ & 0.058 & 0.785 & 0.996 & 0.892 & 0.063 & 0.455 & 0.872 & 0.678 & 0.410 \\
\hline GS $\times P \times K$ & 0.293 & 0.999 & 0.922 & 0.960 & 0.117 & 0.970 & 0.970 & 0.866 & 0.538 \\
\hline \multicolumn{10}{|c|}{ High soil fertility } \\
\hline Factors & \multicolumn{9}{|c|}{ Anova (F probability) } \\
\hline Phosphorus rates $(\mathrm{P})$ & 0.320 & $<0.01$ & 0.09 & 0.054 & 0.200 & 0.953 & 0.105 & $<0.01$ & 0.497 \\
\hline Potassium rates $(\mathrm{K})$ & 0.046 & 0.001 & 0.001 & 0.261 & 0.210 & 0.005 & 0.230 & 0.484 & 0.124 \\
\hline$P \times K$ & 0.5751 & 0.564 & 0.699 & 0.757 & 0.810 & 0.605 & 0.491 & 0.852 & 0.460 \\
\hline
\end{tabular}

* Means followed by different letters differ by the Tukey test at $\mathrm{p} \leq 0.05$.

Table 3. Variance analyses for the number of tillers (NT), panicle density (PD), panicle biomass (PB) and grain yield (GY) of lowland rice 'IRGA 424' cultivar, as affected by $\mathrm{P}_{2} \mathrm{O}_{5}$ and $\mathrm{K}_{2} \mathrm{O}$ rates and growing season, in areas with low and high soil fertility.

\begin{tabular}{|c|c|c|c|c|}
\hline \multicolumn{5}{|c|}{ Low soil fertility } \\
\hline \multirow[b]{2}{*}{ Growing season } & NT & PD & $\mathrm{PB}$ & GY \\
\hline & unit & $\mathrm{m}^{-2}$ & $\mathrm{~g}$ & $\mathrm{~kg} \mathrm{ha}^{-1}$ \\
\hline $2010 / 2011$ & $2.5 \mathrm{a}$ & $363 \mathrm{a}$ & 1.64 & $6,062 \mathrm{a}$ \\
\hline $2011 / 2012$ & $1.9 \mathrm{~b}$ & $280 \mathrm{~b}$ & 1.73 & $4,929 \mathrm{~b}$ \\
\hline Factors & \multicolumn{4}{|c|}{ Anova (F probability) } \\
\hline Growing seasons (GS) & $<0.01$ & $<0.01$ & 0.043 & $<0.01$ \\
\hline Phosphorus rates $(\mathrm{P})$ & $<0.01$ & $<0.01$ & $<0.01$ & $<0.01$ \\
\hline Potassium rates $(\mathrm{K})$ & 0.331 & 0.351 & 0.154 & 0.078 \\
\hline GS x P & 0.482 & 0.182 & $<0.01$ & 0.140 \\
\hline GS x K & 0.458 & 0.176 & 0.787 & 0.136 \\
\hline $\mathrm{P} \times \mathrm{K}$ & 0.282 & 0.349 & 0.858 & 0.333 \\
\hline GS $x \mathrm{P} \times \mathrm{K}$ & 0.311 & 0.098 & 0.106 & 0.077 \\
\hline \multicolumn{5}{|c|}{ High soil fertility } \\
\hline Factors & \multicolumn{4}{|c|}{ Anova (F probability) } \\
\hline Phosphorus rates $(\mathrm{P})$ & 0.373 & 0.303 & 0.128 & 0.353 \\
\hline Potassium rates $(\mathrm{K})$ & 0.022 & $<0.02$ & $<0.01$ & 0.023 \\
\hline $\mathrm{P} \times \mathrm{K}$ & 0.382 & 0.078 & 0.496 & 0.636 \\
\hline
\end{tabular}

* Means followed by the same letter do not differ by the Tukey test at $\mathrm{p} \leq 0.05$. 
Therefore, the effects of $\mathrm{P}$ and $\mathrm{K}$ variables were presented and discussed separately.

The $\mathrm{N}, \mathrm{P}, \mathrm{K}$ and $\mathrm{Cu}$ contents in rice leaves were affected by applied $\mathrm{K}$ on the high fertility area (Table 2). There is a positive interaction between the absorption of N, P and $\mathrm{K}$ and $\mathrm{K}$ fertilization (Fageria 2009, Fageria et al. 2011b). In other words, the increase in $\mathrm{K}$ fertilization induced the enhanced absorption of $\mathrm{N}, \mathrm{P}$ and $\mathrm{K}$, which was reflected in the levels of these nutrients in rice leaves (Figure 2). On the other hand, according to the aforementioned authors, there is an inverse interaction between $\mathrm{K}$ and $\mathrm{Cu}$ contents, wherein the increased absorption of $\mathrm{K}$ reduces the absorption of $\mathrm{Cu}$, as observed in this experiment.

The nutrient content in rice leaves, tillering, panicle density, panicle mass and grain yield were not affected by the $\mathrm{K}$ rates under low fertility conditions (Tables 2 and 3). These results may be due to the low $\mathrm{pH}$ found in the area in the two growing seasons (Table 1). Potassium, that has a valence $\mathrm{K}^{+1}$, has a

(A)
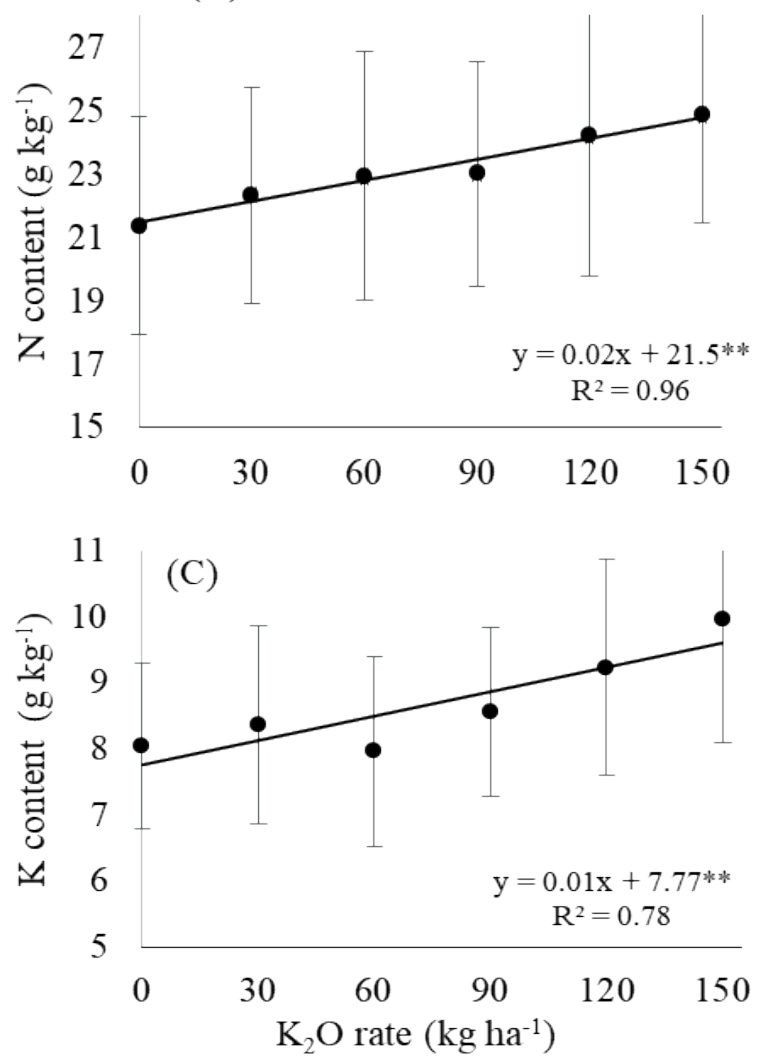

lower retention rate by soil particles than $\mathrm{Ca}^{+2}$ and $\mathrm{Mg}^{+2}$, which have a higher valence (Werle et al. 2008). Moreover, a low $\mathrm{pH}$ negatively affects the $\mathrm{K}$ availability for crop uptake (Malavolta 2006). In tropical soils, well drained and with low cation exchange capacity, such as the Brazilian or African Savannah soils, there is a greater leaching of K. For instance, the water used for irrigation of rice cultivated in the Tocantins state comes from the topsoil and goes to the river carrying nutrients like $\mathrm{K}$ (Cassman et al. 1996, Dobermann \& White 1999, Fageria 2015). This condition may be aggravated by the flooding of the area, as happened in this experiment. Santos et al. (1999), who studied different levels of $\mathrm{K}$ and different water management scenarios in tropical soils, showed that, in a continuous water flooding, fractional $\mathrm{K}$ fertilization increased its utilization efficiency, because it reduced its leaching. Thus, the application of increasing rates of $\mathrm{K}$ did not provide significant increases in the evaluated parameters, probably due to the low $\mathrm{pH}$ and the predominance
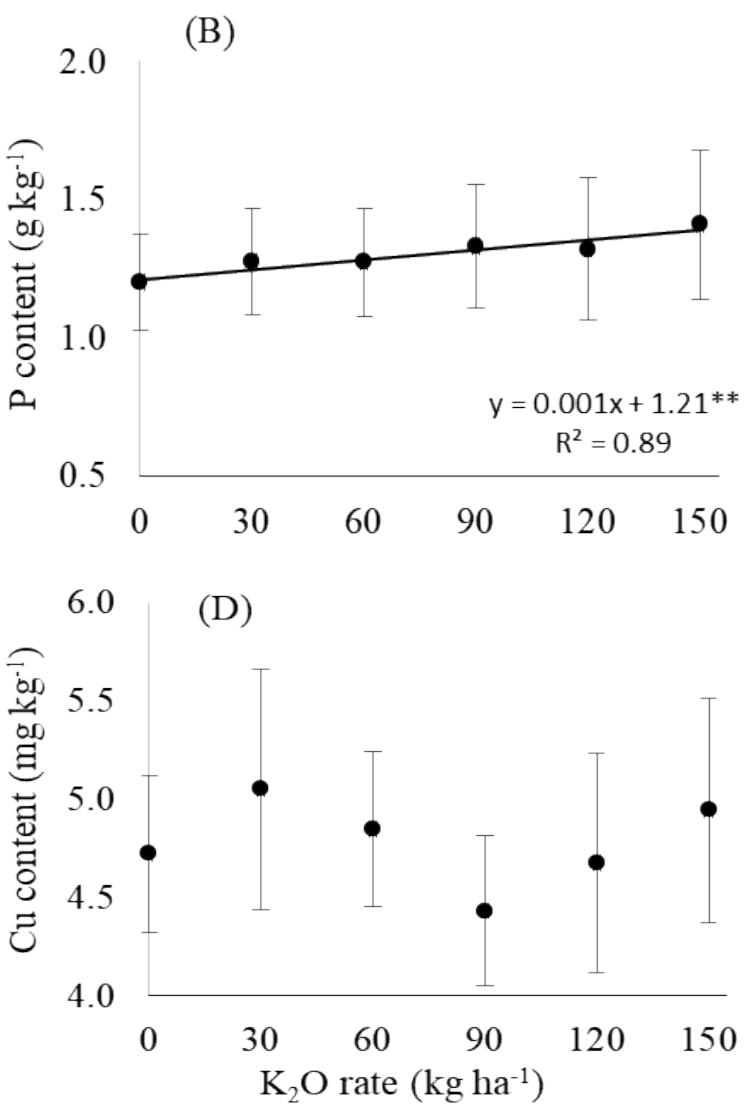

Figure 2. Nitrogen (A), phosphorus (B), potassium (C) and copper (D) contents in lowland rice flag leaf, as affected by rates of $\mathrm{K}_{2} \mathrm{O}$, in an area with high fertility soil, in the 2011/2012 growing season. Linear models followed by * or ** indicate a significant probability $(<5 \%$ or $<1 \%$, respectively). 
of positive charges in the soil, and that is probably why $\mathrm{K}$ was leached and was not available for plants.

On the other hand, at higher $\mathrm{pH}$ conditions, with less predominance of positive charges in the soil (Table 1), it is likely that $\mathrm{K}$ was less leached and became available to plants, as observed in the experiment with corrected soil. In this sense, there was an effect of $\mathrm{K}$ rates in plant tillering, panicle density, mass panicle and grain yield (Table 3; Figure 3). Likewise, Zaratin et al. (2004) observed the influence of $\mathrm{K}$ fertilization in the yield components of rice grains, in a Brazilian Savannah Oxisol with a $\mathrm{K}$ content of $0.21 \mathrm{cmol}_{\mathrm{c}} \mathrm{kg}^{-1}$ (similar to the level of

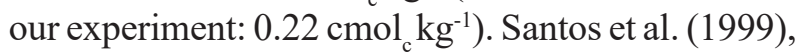
working in a tropical soil with water flooding, showed that, in an area with $\mathrm{pH}$ (water) 4.9 and a level of $\mathrm{K}=$ $0.18 \mathrm{cmol}_{\mathrm{c}} \mathrm{kg}^{-1}$ (lower levels than in our experiment), split potassium fertilization provided increases in the number of grains per panicle and rice grain yield, in relation to the lowest $\mathrm{K}$ levels. Other studies on $\mathrm{K}$ level effects, in rice grown on the floodplains of the
Tocantins state, also reported significant increases in rice yield components and grain yield associated with this nutrient (Fageria et al. 1990, Fageria 2015). Thus, it seems that fertilization with $\mathrm{K}$ may provide an increased yield of rice grains, especially in soils with K deficiency. According to Fageria (2015), in Africa, $17 \%$ of the agricultural area is potassiumdeficient, $21 \%$ in Asia and $29 \%$ in Latin America.

In the low fertility soil area, there was a significant effect of applied $P$ rates in all the nutrients contents in rice leaves, except for Fe (Table 2; Figure 4). The increase of $P$ availability in the soil has a positive relationship with the levels of most nutrients (Malavolta 2006). Thus, as P levels in the soil were low (3.0 mg kg-1 and $3.1 \mathrm{mg} \mathrm{kg}^{-1}$ in the two growing seasons, respectively; Table 1), it is likely that the application of $\mathrm{P}$ increases the levels of nutrient uptake by plants. Fageria \& Baligar (1995), working on an irrigated area, showed that, even in a soil with low $\mathrm{pH}$ (4.4 in water), like in the present experiment (Table 1), an increase of $\mathrm{P}$ rates leads to
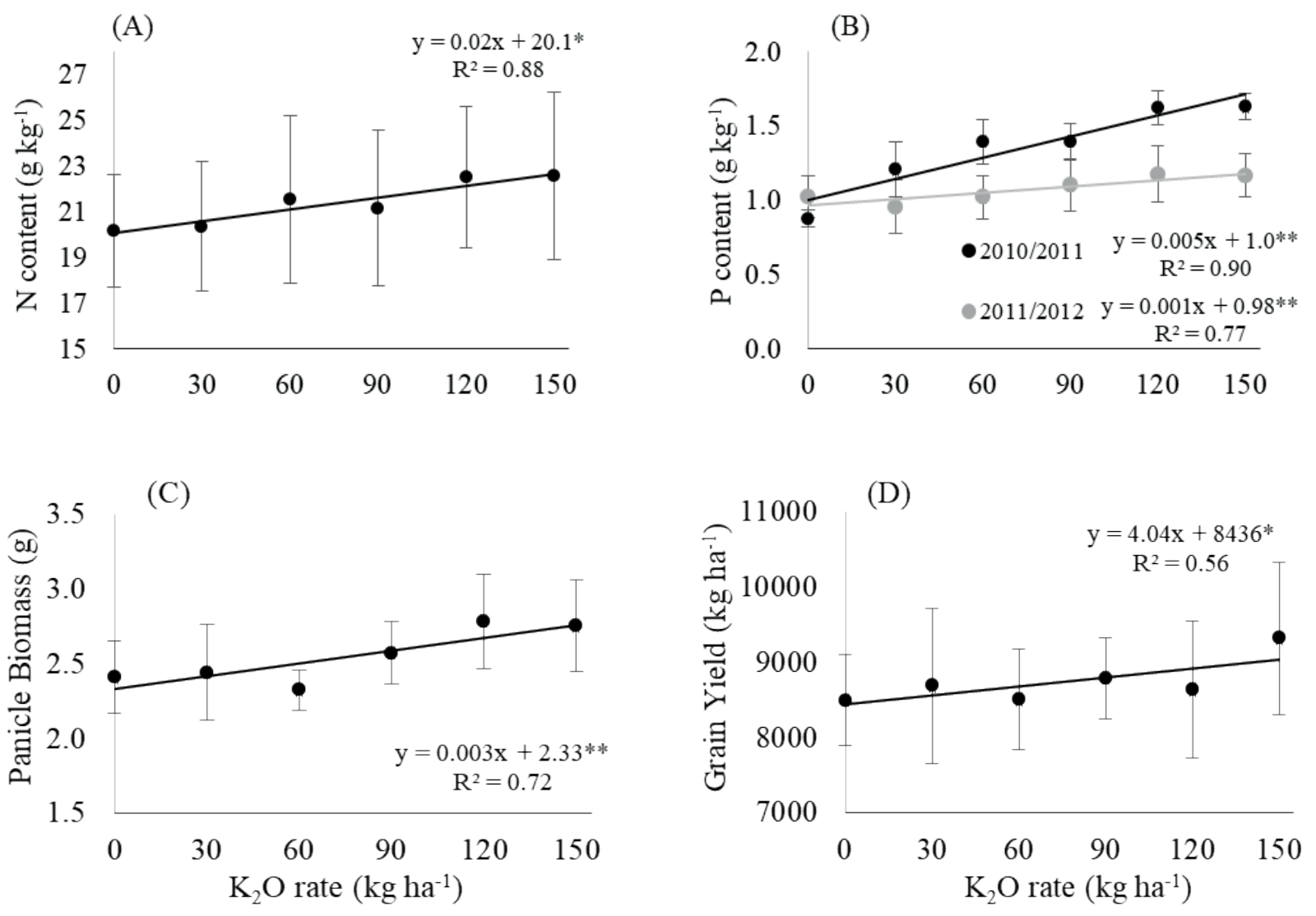

Figure 3. Number of tillers per plant (A), panicle density (B), panicle biomass (C) and grain yield (D) of lowland rice, as affected by rates of $\mathrm{K}_{2} \mathrm{O}$, in an area with high soil fertility, in the 2011/2012 growing season. Linear models followed by * or ** indicate a significant probability $(<5 \%$ or $<1 \%$, respectively). 
an increase in the absorption of all nutrients. Besides, Fageria \& Santos (2007) reported that lowland tropical rice is affected by different levels of P. High levels of this nutrient provide increases in panicle length, panicle number, harvest index and grain yield.

As the area was flooded only at 45 days after sowing, and the chemical changes due to anaerobic
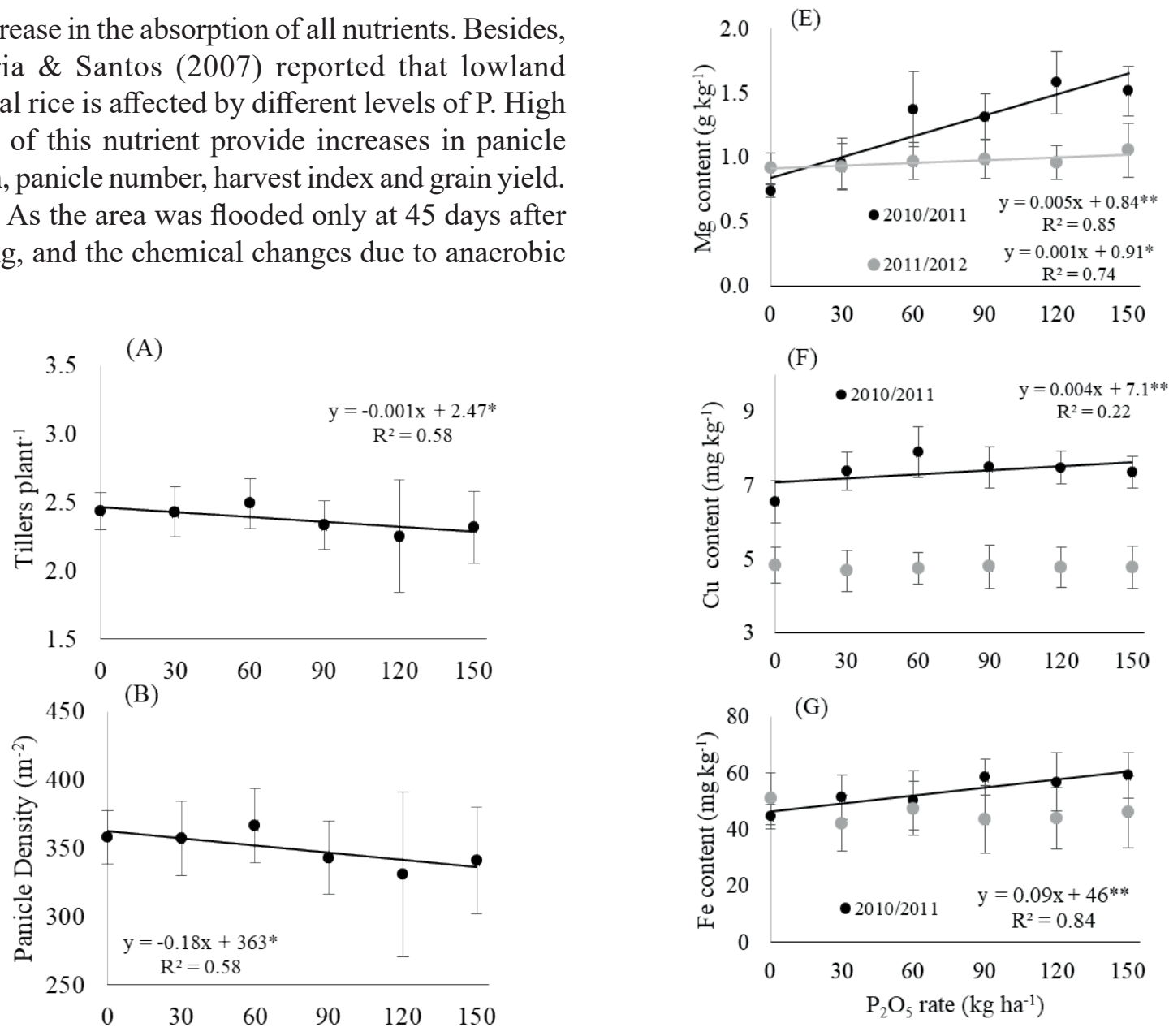

(F)
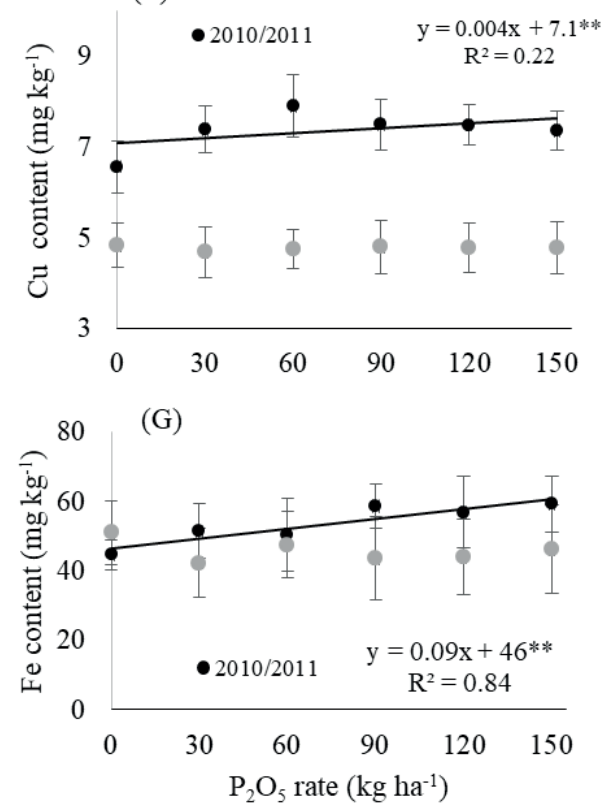

(C)
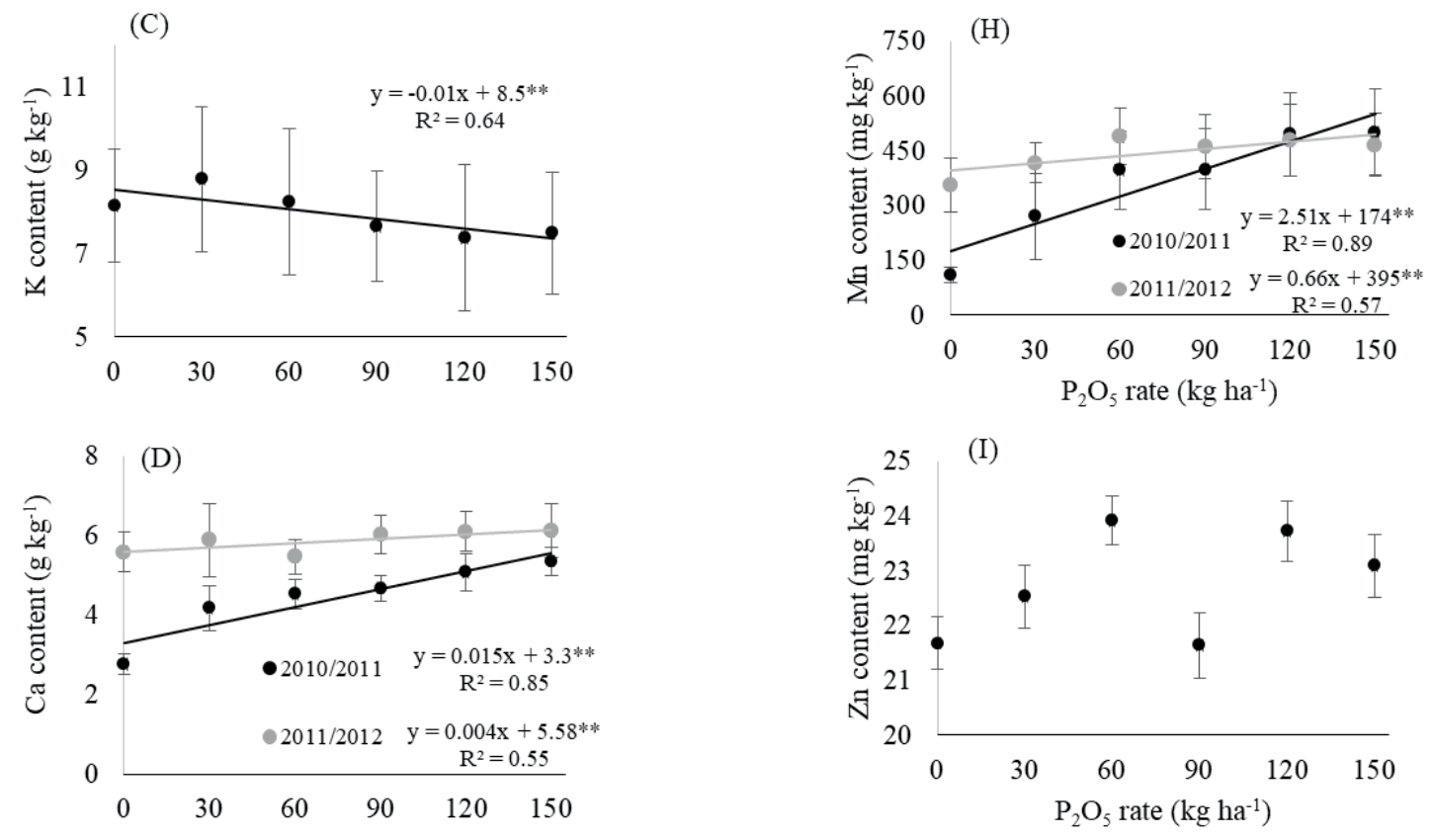

Figure 4. Nitrogen (A), phosphorus (B), potassium (C), calcium (D), magnesium (E), copper (F), iron (G), manganese (H) and zinc (I) contents in lowland rice flag leaf, as affected by rates of $\mathrm{P}_{2} \mathrm{O}_{5}$, in an area with low soil fertility. For N, $\mathrm{K}$ and $\mathrm{Zn}$, dataset is the average of the 2010/2011 and 2011/2012 growing seasons. Linear models followed by * or ** indicate a significant probability $(<5 \%$ or $<1 \%$, respectively). 
condition takes place roughly after 4-5 weeks after the soil submergence (Ponnamperuma 1972), it is safe to assume that the time redox potential increased the $\mathrm{P}$ availability, since the rice crop was in the final stage of development with low P demand. Therefore, the process of $\mathrm{P}$ changes in the soil occurred under aerobic conditions. Thus, the application of phosphate fertilizers in soil with low $\mathrm{pH}$ favors the phosphorus chemisorption in $\mathrm{Fe}$ and $\mathrm{Al}$ complexes (Laboski \& Lamb 2003). These clay minerals are abundant in weathered soils and have groups $\mathrm{OH}^{-}$and $\mathrm{OH}_{2}^{+}$that are released into the soil solution, during the adsorption process (Barrow 1986), potentially enabling an increased soil $\mathrm{pH}$. The application of $\mathrm{P}$, in our trial, was located in the sowing furrow, beside and below seed deposition. So, it is likely that, in this place, an $\mathrm{OH}^{-}$release site was formed, which corrected the $\mathrm{pH}$ near to the plants rhizosphere. Then, the beneficial effect of plant development and increased absorption of nutrients maybe are due, in part, to the increase of the soil $\mathrm{pH}$, as a result to $\mathrm{P}$ applying.

In the high fertility area, there was only a linear effect on the content of $\mathrm{P}$ and $\mathrm{Mn}$ in rice leaves, in response to $\mathrm{P}$ rates (Table 2; Figure 5). There is a positive relationship between $\mathrm{P}$ and $\mathrm{Mn}$, since an increase in the availability of $\mathrm{P}$ is followed by an increased absorption of Mn (Malavolta 2006).

As the rates of $\mathrm{P}$ applied to the soil increase, an increase in the P content of the leaves is expected. Fageria et al. (2013) also reported an increase of $\mathrm{P}$ concentrations in plant tissue associated with increasing $\mathrm{P}$ rates in the soil. However, the low response of other nutrients to increases in $\mathrm{P}$ may be due to the high nutrient content of the soil (13 $\mathrm{mg} \mathrm{kg}^{-1}$; Table 1). According to Sousa \& Lobato

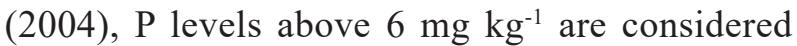
sufficient for irrigated rice. For Fageria et al. (2011a), values of $P$ in soil equal to or greater than $13 \mathrm{mg} \mathrm{kg}^{-1}$ are considered high for flooded rice. The relative productivity of rice is $90 \%$ of the yield potential, when the critical level of $\mathrm{P}$ in the soil is $15 \mathrm{mg} \mathrm{kg}^{-1}$ and there is no response to the application of P fertilization (Beegle et al. 1998). According to Fageria et al. (1997), in lowland conditions, rice does not increase grain yield when levels of $\mathrm{P}$ are greater than $13-15 \mathrm{mg} \mathrm{kg}^{-1}$.

In low fertility conditions, morphological parameters (tillering, density, panicle mass and grain yield) were not significantly influenced by $\mathrm{P}$ rates (Table 3; Figure 6). On average, for the 2010/2011 and 2011/2012 growing seasons, the maximum yield was $7,161 \mathrm{~kg} \mathrm{ha}^{-1}$ for $140 \mathrm{~kg} \mathrm{ha}^{-1}$ of $\mathrm{P}$. This positive relationship was expected as $\mathrm{P}$ content in the soil was low (Table 1) and the application of nutrients via fertilization provided significant increases. Likewise, Fageria \& Baligar (1995) reported increases in biomass and nutrient uptake by rice in low fertility soil ( $\mathrm{pH}$ of 4.4 in water), in response to the application of increasing P rates. Other authors have also reported a response of lowland rice to $\mathrm{P}$ fertilization (Fageria 1989, Fageria \& Zimmermann 1996).

However, effects of the application of $\mathrm{P}$ in the high fertility soil were not observed. This may be explained by the high nutrient content of the soil
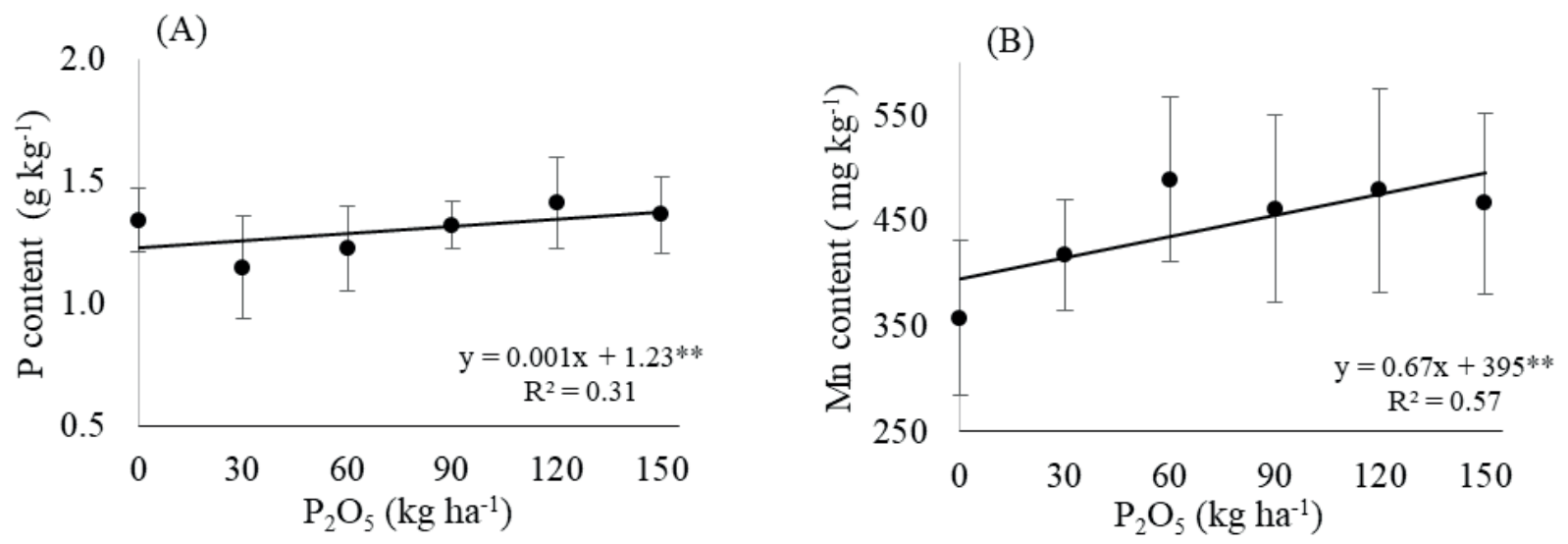

Figure 5. Phosphorus (A) and Mn (B) contents in lowland rice, as affected by rates of $\mathrm{P}_{2} \mathrm{O}_{5}$, in an area of high soil fertility, in the 2011/2012 growing season. Linear models followed by * or $* *$ indicate a significant probability $(<5 \%$ or $<1 \%$, respectively). 

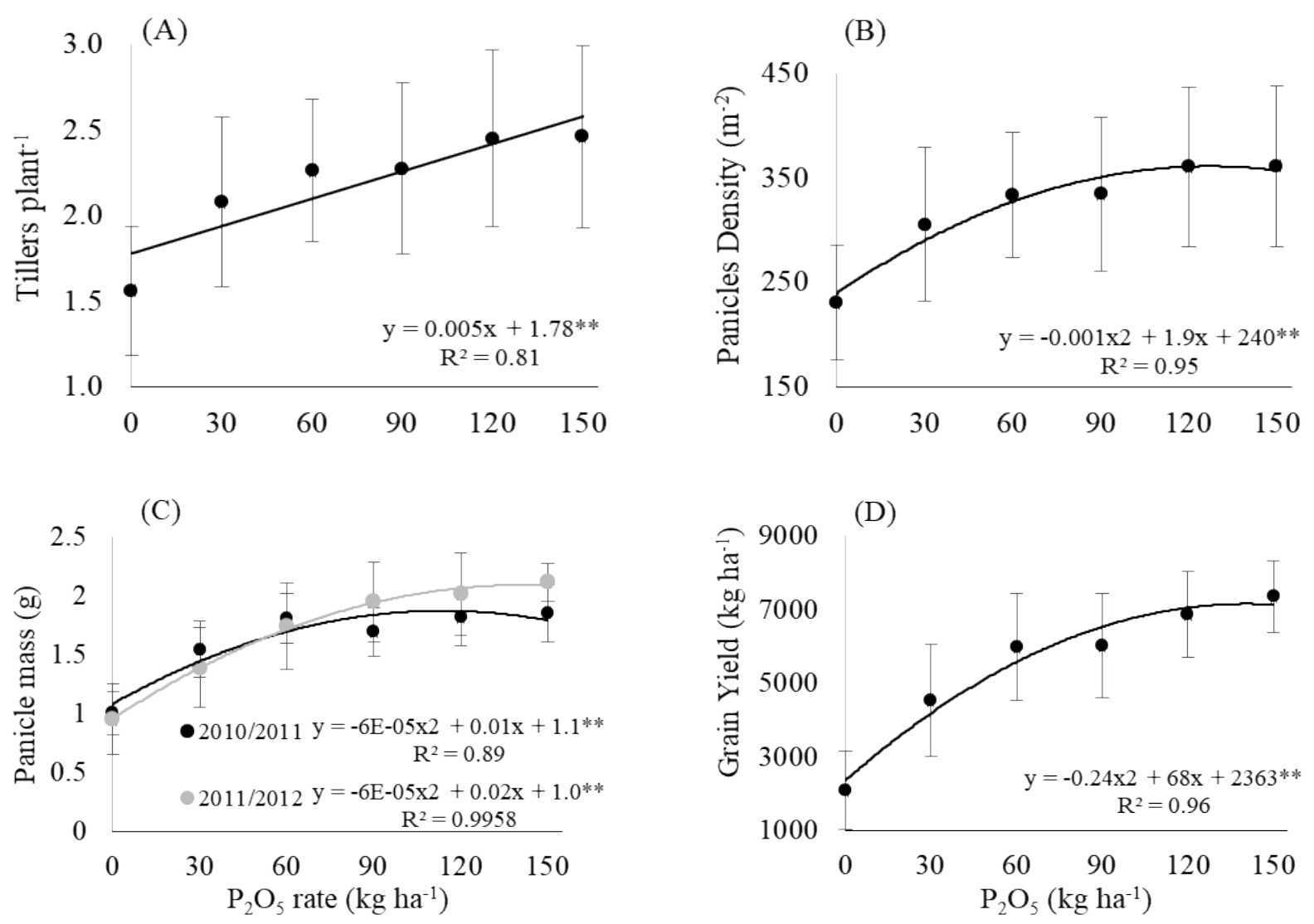

Figure 6. Number of tillers per plant (A), panicle density (B), panicle biomass (C) and grain yield (C) of lowland rice, as affected by rates of $\mathrm{P}_{2} \mathrm{O}_{5}$, in an area with low soil fertility. For number of tillers per plant, number of panicles $\mathrm{m}^{-2}$ and grain yield, dataset is the average of the 2010/2011 and 2011/2012 growing seasons. Models followed by * or ** indicate a significant probability $(<5 \%$ or $<1 \%$, respectively).

(13 mg kg-1; Table 1). In general, the plants showed higher nutrient levels in the 2010/2011 growing season, if compared to the $2011 / 2012$ growing season (Table 2). These results may have affected the morphological parameters of tillering, panicle density and grain yield, which also had higher values in the 2010/2011 growing season (Table 3). Well-nourished plants tend to reach a higher grain yield than plants that have some nutrient limitation (Fageria 2009, Crusciol et al. 2016).

Based on the results obtained, it can be inferred that, in low fertility soils, the P application provides significant increases in the rice grain yield, in flooded tropical soil conditions. On the other hand, in this condition, the application of $\mathrm{K}$ does not increase plant nutrition and grain yield. In adequate chemical conditions, with high $\mathrm{P}$ content in the soil, $\mathrm{P}$ fertilization does not provide significant increases in rice grain yield in the tropical floodplains of the Tocantins state. In in this case, the $\mathrm{K}$ fertilization contributes significantly to an increased rice grain yield.

\section{CONCLUSIONS}

1. There were no interactions between the $\mathrm{P}$ and $\mathrm{K}$ fertilizer rates for leaf content of $\mathrm{N}, \mathrm{P}, \mathrm{K}, \mathrm{Ca}, \mathrm{Mg}$, $\mathrm{Cu}, \mathrm{Fe}, \mathrm{Mn}, \mathrm{Zn}$ and biometric parameters, such as tillering, yield components and grain yield of lowland rice, in tropical floodplains;

2. In low-fertility conditions, there was a response in plant nutrition, tillering, yield components and grain yield of lowland rice, in tropical floodplains, due to $\mathrm{P}$ fertilization, but there was not for $\mathrm{K}$ fertilization;

3. In high fertility conditions, there was a response in plant nutrition, tillering, yield components and grain yield of lowland rice, in tropical floodplains, due to $\mathrm{K}$ fertilization, but there was no effect due to $\mathrm{P}$ fertilization. 


\section{REFERENCES}

ALLEONI, L. R. F. et al. Acidity and aluminum speciation as affected by surface liming in tropical no-till soils. Soil Science Society of America Journal, v. 74, n. 3, p. 10101017, 2010.

ALVARES, C. L. et al. Köppen's climate classification map of Brazil. Meteorologische Zeitschrift, v. 22, n. 6, p. 711-728, 2014.

BARBERENA, D. S. da S.; MEDEIROS, R. D. de; BARBOSA, G. F. Desenvolvimento e produtividade de arroz irrigado em resposta a diferentes doses de fósforo e potássio, em várzea de primeiro ano, no estado de Roraima. Ciência e Agrotecnologia, v. 35, n. 3, p. 462-470, 2011.

BARROW, N. J. J. Reaction of anions and cations with variable-charge soils. Advances in Agronomy, v. 38, n. 1, p. 183-230, 1986.

BEEGLE, D.; SHARPLEY, A.; GRAETZ, D. Interpreting soil test phosphorus for environmental purposes. In: THOMAS, J. (Ed.). Soil testing for phosphorus: environmental uses and implications. Newark: University of Delaware, 1998. p. 31-40.

CAIRES, E. F. et al. Crescimento radicular e nutrição da soja cultivada no sistema plantio direto em resposta ao calcário e gesso na superfície. Revista Brasileira de Ciência do Solo, v. 25, n. 4, p. 1029-1040, 2001.

CASSMAN, K. G. et al. Nitrogen-use efficiency in tropical lowland rice systems: contributions from indigenous and applied nitrogen. Field Crops Research, v. 47, n. 1, p. 1-12, 1996.

COELHO, M. R. et al. The soils. In: SANTOS, A. B.; STONE, L. F.; VIEIRA, N. R. A. (Eds.). The rice crop in Brazil. 2. ed. Santo Antônio de Goiás: Embrapa Arroz e Feijão, 2006. p. 161-208.

CRUSCIOL, C. A. C. et al. Doses de fósforo e crescimento radicular de cultivares de arroz de terras altas. Bragantia, v. 64 , n. 4 , p. 643-649, 2005.

CRUSCIOL, C. A. C. et al. Macronutrient uptake and removal by upland rice cultivars with different plant architecture. Revista Brasileira de Ciência do Solo, v. 40, n. 1, p. 1-20, 2016.

CRUSCIOL, C. A. C. et al. Upland rice growth and mineral nutrition as affected by cultivars and sulfur availability. Soil Science Society of America Journal, v. 77, n. 1, p. 328-335, 2013.

DOBERMANN, A.; WHITE, P. F. Strategies for nutrient management in irrigated and rainfed lowland rice systems. In: BALASUBRAMANIAN, V.; LADHA, J. K.; DENNING, G. L. (Eds.). Resource management in rice systems: nutrients. Dordrecht: Springer, 1999. p. 1-26.
FAGERIA, N. K. Efeito da calagem na produção de arroz, feijão, milho e soja em solo de Cerrado. Pesquisa Agropecuária Brasileira, v. 36, n. 11, p. 1419-1424, 2011 b.

FAGERIA, N. K. et al. Chemistry of lowland rice soils and nutrient availability. Communications in Soil Science and Plant Analysis, v. 42, n. 16, p. 1913-1933, 2011a.

FAGERIA, N. K. et al. Lowland rice response to potassium fertilization and its effect on $\mathrm{N}$ and $\mathrm{P}$ uptake. Fertilizer Research, v. 21, n. 3, p. 157-162, 1990.

FAGERIA, N. K. et al. Nitrogen uptake and use efficiency in rice. In: RAKSHIT, A.; SINGH, H. B.; SEN, A. (Eds.). Nutrient use efficiency: from basics to advances. New Delhi: Springer, 2015. p. 285-296.

FAGERIA, N. K. et al. Potassium soil test calibration for lowland rice on an Inceptisol. Communications in Soil Science and Plant Analysis, v. 41, n. 21, p. 2595-2601, 2010.

FAGERIA, N. K. Potassium requirements of lowland rice. Communications in Soil Science and Plant Analysis, v. 46, n. 12, p. 1459-1472, 2015.

FAGERIA, N. K. Solos tropicais e aspectos fisiológicos das culturas. Brasília, DF: Embrapa-DPU, 1989.

FAGERIA, N. K. The use of nutrients in crop plants. Boca Raton: CRC Press, 2009.

FAGERIA, N. K.; BALIGAR, V. C. Response of lowland rice and common bean grown in rotation to soil fertility levels on a varzea soil. Fertilizer Research, v. 45, n. 1, p. 13-20, 1995.

FAGERIA, N. K.; KNUPP, A. M.; MORAES, M. F. Phosphorus nutrition of lowland rice in tropical lowland soil. Communications in Soil Science and Plant Analysis, v. 44, n. 20, p. 2932-2940, 2013.

FAGERIA, N. K.; MOREIRA, A.; CASTRO, C. Response of soybean to phosphorus fertilization in Brazilian Oxisol. Communications in Soil Science and Plant Analysis, v. 42, n. 22, p. 2716-2723, 2011c.

FAGERIA, N. K.; NASCENTE, A. S. Management of soil acidity of South American soils for sustainable crop production. Advances in Agronomy, v. 128, n. 1, p. 221275, 2014.

FAGERIA, N. K.; SANTOS, A. B.; BALIGAR, V. C. Phosphorus soil test calibration for lowland rice on an Inceptisol. Agronomy Journal, v. 89, n. 5, p. 737-742, 1997.

FAGERIA, N. K.; SLATON, N. A.; BALIGAR, V. C. Nutrient management for improving lowland rice productivity and sustainability. Advances in Agronomy, v. 80, n. 1, p. 63-152, 2003. 
FAGERIA, N. K.; ZIMMERMANN, F. J. P. Resposta do arroz irrigado à adubação residual e aos níveis de adubação em solo de várzea. Pesquisa Agropecuária Brasileira, v. 31, n. 6, p. 463-446, 1996.

FARINELLI, R. et al. Características agronômicas de arroz de terras altas sob plantio direto e adubação nitrogenada e potássica. Revista Brasileira de Ciência do Solo, v. 28, n. 3, p. 447-454, 2004.

GEORGE, T. et al. Upland rice response to phosphorus fertilization in Asia. Agronomy Journal, v. 93, n. 6, p. 1362$1370,2001$.

HEINEMANN, A. B. et al. Upland rice cultivar responses to row spacing and water stress across multiple environments. Experimental Agriculture, v. 53, n. 4, p. 609-626, 2017.

LABOSKI, C. A. M.; LAMB, J. A. Changes in soil test phosphorus concentration after application of manure or fertilizer. Soil Science Society of America Journal, v. 67, n. 2, p. 544-554, 2003.

MALAVOLTA, E. Manual de nutrição mineral de plantas. São Paulo: Agronômica Ceres, 2006.

NASCENTE, A. S. et al. Gypsum and phosphorus in the development of upland rice under a no-tillage system. African Journal of Agricultural Research, v. 9, n. 50, p. 3645-3654, 2014.

NASCENTE, A. S.; COBUCCI, T. Soil phosphorus availability and dry bean yield as affected by the application of liquid calcium carbonate micron particles on the furrow. African Journal of Agricultural Research, v. 10, n. 15, p. $1840-1851,2015$.

NASCENTE, A. S.; CRUSCIOL, C. A. C.; COBUCCI, T. The no-tillage system and cover crops: alternatives to increase upland rice yields. European Journal of Agronomy, v. 45, n. 1, p. 124-131, 2013.

NELSON, K. A. et al. Soybean response to preplant and foliar-applied potassium chloride with strobilurin fungicides. Agronomy Journal, v. 102, n. 6, p. 1657-1663, 2010 .

PAGANI, A.; MALLARINO, A. P. Soil pH and crop grain yield as affected by the source and rate of lime. Soil Science Society of America Journal, v. 76, n. 5, p. 1877-1886, 2012.
PONNAMPERUMA, F. N. The chemistry of submerged soils. Advances in Agronomy, v. 24, n. 1, p. 29-96, 1972.

QIAN, Y. L.; FRY, J. D.; UPHAM, W. S. Rooting and drought avoidance of warm-season turfgrasses and tall fescue in Kansas. Crop Science, v. 37, n. 3, p. 905-910, 1997.

ROWLAND, J. H. et al. Optimal nitrogen and potassium fertilization rates for establishment of warm-season putting greens. Agronomy Journal, v. 102, n. 6, p. 1601-1605, 2010 .

SANTOS, A. B. et al. Manejo de água e de fertilizante potássico na cultura de arroz irrigado. Pesquisa Agropecuária Brasileira, v. 34, n. 4, p. 565-573, 1999.

SANTOS, H. G. dos et al. Sistema brasileiro de classificação de solos. 2. ed. Rio de Janeiro: EmbrapaCNPS, 2006.

SILVA, F. C. Manual de análises químicas de solos, plantas e fertilizantes. Campinas: Embrapa-CNPTIA, 1999.

SLATON, N. A. et al. Correlation and calibration of soil potassium availability with rice yield and nutritional status. Soil Science Society of America Journal, v. 73, n. 4, p. 1192-11201, 2009.

SOUSA, D. M. G.; LOBATO, E. Cerrado: correção do solo e adubação. 2. ed. Brasília, DF: Embrapa Informação Tecnológica/Embrapa-CPA, 2004.

SOUZA, H. A. de et al. Calagem e adubação boratada na produção de feijoeiro. Revista Ciência Agronômica, v. 42, n. 2, p. 249-257, 2011.

UNITED STATES DEPARTMENT OF AGRICULTURE (USDA). Keys to soil taxonomy. 12. ed. Washington, DC: USDA-Natural Resources Conservation Service, 2014.

WERlE, R.; GARCiA, R. A.; ROSOlEM, C. A. Lixiviação de potássio em função da textura e da disponibilidade do nutriente no solo. Revista Brasileira de Ciência do Solo, v. 32, n. 6, p. 2297-2305, 2008.

ZARATIN, C. et al. Efeitos de quatro doses de potássio em seis cultivares de arroz irrigados por aspersão: II. Rendimento de benefício e de grãos inteiros. Científica, v. 32, n. 2, p. 115-120, 2004. 